observable when the secretion (with half-digested hairs) was kept in a moist chamber after removal from the intestine. Animals fed with cotton wool or filter-paper (made inviting to the animal by covering it with a thin film of casein and wool-fat) gave scarcely any nitroprusside reaction, but the reaction reappeared when cystin was added to this food (although this is left quite undigested by the animal).

It was therefore assumed that the secretion contains an agent capable of reducing the $S-S$ bonds in the hair (see Astbury ${ }^{1}$ and Speakman ${ }^{2}$, Goddard and Michaelis ${ }^{3}$ ) but auto-oxidisable in the air. The reduction of the hair keratin opens its peptide chains to the attack of the proteinase (Goddard and Michaelis) the activity of which is but little influenced by the low oxidation-reduction potential of the medium. The nature of the reducing agent is unknown. It is not a thiol compound. Its reducing power may be estimated from the accompanying table, which records some experiments on the reduction of certain dyes in the middle intestine (see also Titschack ${ }^{4}$ ).

\begin{tabular}{|c|c|c|c|}
\hline Dye & $\begin{array}{l}E_{h} \text { at } \\
p \mathbf{H} 10\end{array}$ & $\begin{array}{c}\text { Animals fed } \\
\text { with wool } \\
\text { stained with } \\
\text { dyes. SH }+ \text {. } \\
\text { (Reducing agent } \\
\text { having reacted } \\
\text { with } \mathrm{S}-\mathrm{S} \text { ) }\end{array}$ & $\begin{array}{l}\text { Animals fed } \\
\text { with cotton } \\
\text { wool stained } \\
\text { with dyes. } \\
\text { SH - ("Pure } \\
\text { reducing } \\
\text { agent") }\end{array}$ \\
\hline $\begin{array}{l}\text { Methylene blue } \\
\text { Indigo tetrasulphonate } \\
\text { Indigo disulphonate } \\
\text { Gallophenine } \\
\text { Brilliant alizarine blue } \\
\text { Rosinduline GG. }\end{array}$ & $\begin{array}{l}-0 \cdot 08 \\
-0 \cdot 13 \\
-0 \cdot 22 \\
-0 \cdot 29 \\
-0 \cdot 34 \\
-0 \cdot 44\end{array}$ & $\begin{array}{c}\text { reduced } \\
\text { partly reduced } \\
\text { not reduced } \\
,,\end{array}$ & $\begin{array}{c}\text { reduced } \\
\text { partly reduced } \\
\text { not rëduced } \\
\text {," }\end{array}$ \\
\hline
\end{tabular}

Experiments on the digestion of sheep wool by the moth proteinase in vitro using sodium thioglycolate as reducing agent at $p \mathrm{H} 10$ (Goddard, Michaelis) showed a rapid splitting-up of the wool with formation of equivalent quantities of amino and carboxylic groups. Under the same conditions pancreatic trypsin-kinase with the same activity towards casein had no effect, due to inhibition by the thiol compounds.

The experiments are being continued.

$$
\text { K. Linderstrøm-Lang. }
$$

$$
\text { F. Duspiva. }
$$

Carlsberg Laboratorium, København. May 23.

${ }^{1}$ W. T. Astbury, Trans. Faraday Soc., 29, 103; 1933. 2 J. B. Speakman and Hirst, M.C., Trans. Faraday Soc., 29, 148 ; 1933.

D. R. Goddard and L. Michaelis, J. Biol. Chem., 106, 605; 1934. - E. Titschack, Z. tech. Biol., 10, $92 ; 1922$.

\section{Mechanism of Respiration}

IN a previous letter ${ }^{1}$, I discussed the respiration of the minced breast muscle of the pigeon. In this material succinic acid seems to play by its reversible two-step oxidation to fumaric and hydroxyfumaric acid an important rôle as catalytic hydrogen carrier.

Dr. K. A. C. Elliott ${ }^{2}$ ascribes my results to a simple methodic error, and doubts the possibility of generalisation. Owing to the nature and bulk of evidence, discussion is impossible within the limits of these columns. I must refer to the complete paper which I hope to publish soon. Our recent experiments confirm our previous results and show that at any rate a limited generalisation is warranted. Of the two steps of oxidation : succinic to fumaric acid and fumaric to hydroxyfumaric acid, the latter is quantitatively the more important. Malic acid is not activated. The apparent activation of this substance is due to the presence of fumarase. This might explain Elliott's results.

Institute of Medical Chemistry

A. Szent-Györgyi.

University, Szeged,

Hungary.

May 15.

1 Nature, 135, 305, Feb. 23, 1935.

2 Nature, 135, 762, May 4, 1935 .

\section{Giant Cells in Insects Parasitised by Hymenopterous Larvæ}

IN a recent paper, A. Paillot ${ }^{1}$ directs attention to the giant cells present in aphids parasitised by Hymenoptera, and he affirms that these cells originate from the sexual cells of the host. In support of this conclusion, Paillot states that he has once observed in a female of Chaitophorus aceris, parasitised by Aphidius ribis, Hal. a group of cells (considered by him to be germinal cells) in process of dispersion, and that these elements already showed the structure of giant cells.

Giant cells, appearing as opaque white globules of various sizes, are invariably present in weevils of Sitona lineata, L., containing immature larvæ of the braconid, Dinocampus (Perilitus) rutilus, Nees. Investigation ${ }^{2,3}$ has shown that these cells are the hypertrophied cells of the embryonic membrane of the parasite egg. When the larva emerges from the chorion, the cells of the embryonic membrane dissociate and become free in the body cavity of the host. They then increase greatly in size, absorbing fatty matter from the body fluid. They constitute the principal food of the larva in its later stages. It was found that these cells continued their development even should the parasite larva die young, and they may then attain an abnormally large size. This point is of interest in view of Paillot's statement that he has found giant cells present in aphids without a developing parasite larva, and in such cases he considered that the parasite embryo had been completely reabsorbed.

Dissociation of the cells of the embryonic mem brane, either singly or in groups, and their persistence during parasitism, has been observed in various parasitic Hymenoptera, and the literature on this subject has already been discussed ${ }^{3}$. Since then, a paper by Oglobin ${ }^{4}$ has come to my notice, in which he gives a detailed description of the origin and development of the giant cells in Dinocampus terminatus, and his account agrees in all essentials with my observations on D. rutilus. Further contributions to this subject are to be found in Parker's studies of Macrocentrus gifuensis, Ashmead ${ }^{5}$, and Meteorus nigricollis, Thomson ${ }^{6}$. In the Aphidiini, Spencer ${ }^{7}$ has found that the serosa breaks up into pieces when the larva hatches. The serosal fragments become rounded off and increase in size. They are afterwards eaten by the larva. I have no doubt that these serosal fragments constitute the "giant cells" observed by Paillot.

In an earlier paper ${ }^{8}$, Paillot comments on the giant cells found in caterpillars of Pieris brassicce, and he considers that they originate from the ordinary elements of the blood of the host. He suggests that the influence inducing the hypertrophy of these cells 